\title{
Two-Sided assembly line balancing to minimize number of workstation with considering the relationships between tasks
}

\author{
Dina Rachmawaty ${ }^{1, *}$, Putu Dana Karningsih ${ }^{1}$, and Budi Santosa ${ }^{1}$ \\ ${ }^{1}$ Department of Industrial Engineering, Institut Teknologi Sepuluh Nopember, 60111 Surabaya, \\ Indonesia
}

\begin{abstract}
There are many problems in assembly line. Some of the problems are assembly line reliability which relates to maintenance and unbalance workload. As a result, production line is not efficient and production plan is not fulfilled. Previous research on two-sided assembly line balancing problem has proprosed improvement method by considering index relationship between tasks. There are only two factors that is taken into account in this research, they are: distance factor of the implementation of the task (distance factor) and tools used to perform the task (tool factor). Therefore, this paper aims to develops conceptual model by considering additional factors that affecting Assembly Line Tasks Consistency (ATC). The additional factors that are considered are as follow: distance factor, tool factor, motion factor, layout factor, and skill factor. The purpose of this conceptual model is to increase productivity by minimizing number of workstations. Linear combination are used to find a combination solution of a relationship between task to complete a twosided assembly line balancing problem. Improvement of proposed assembly line are measured according to Balance Delay (BD) and Line Efficiency (LE).
\end{abstract}

\section{Introduction}

Two-sided assembly line is a set of tasks that must be shared and processed on a set of mated-station, each containing two opposing and opposite workstation[1]. Two-sided Assembly Line Balancing Problems (TALBPs) can be classified in a set tasks that must be diveded to and processed on a set of mated-station, each containing two facing and opposite workstations. Two cooperative workers on each mated-station operate the tasks in parallel at both left and right sides. Due to the utilization of both sides, the tasks are portioned into there types, they are L-type tasks, R-type tasks, and E-type tasks. L-type tasks must be allocated to left side, R-type tasks must be allocated to right side whereas E-type task are allocated to either left and right side. Optimization criterion can be divided into three categories, there areTALBP-I with the workstation number minimization criterion, TALBP-

\footnotetext{
* Corresponding author: rachmawaty.dina@gmail.com
} 
II with the cycle time minimazation criterion and TALBP-E with the line efficiency maximization criterion[1].

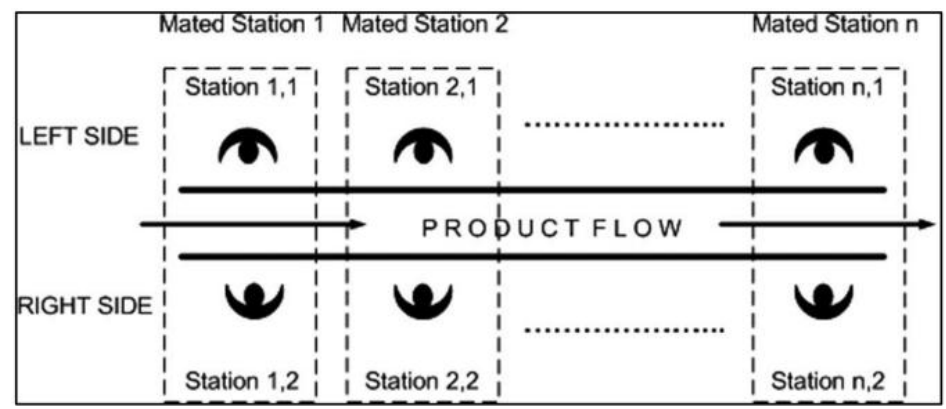

Fig. 1. Two-sided assembly line [2].

Research of [3] a developed relationship between tasks on two-sided assembly line balancing problem according to the index which he has been developed. The relationship factors only have two factors, they are distance factor of the implementation of the task (distance factor) and tools used to perform the task (tool factor). Autor of [3] suggest that in the real condition, more relationships between the tasks for assignment to each station makes assembly line become more effective. Autor of [4] suggest that this line balancing improvement is a traditional approach but it considers relevant criteria to today problem to do because easier to fix at the real object.

This research modifies factors affecting the index of task relations refers to the task relations index developed by[3]. Modification of these factors aims to improve work productivity. Productivity will essentially be related to the production system, a system in which factors such as labor, machinery, work equipment, raw materials, plant layout and so on are managed in an organized way to realize goods or services effectively and efficiently[5]. There are several additional factors that considered in this research, they are: motion factor, layout factor and skill factor. With the addition of these factors, assembly line idle time can be reduced and work becomes effective. Development of conceptual model is carried out by taken into account three performance criteria, namely: number of station, number of mated-station, and Assembly Line Tasks Consistency (ATC). Where the value on the influence factor of relation index and releationship value affecting ATC is not preliminary determined (fix) and to get the best-modified result, the linear combination is used to get the best combination of a solution. This paper aims to develop a conceptual model to minimize the number of workstations for improving line efficiency.

\section{Literature Review}

Two-sided assembly line balancing concept has the main goals of reducing idle time and speeding cycle time, which distinguishes only techniques in reducing idle time itself and developing algorithms used. So far there have been some idle time reduction goals with task restrictions, improved task performance in parallel and consideration of connecting task work. While on algorithm development, some researchers previously used Genetic Algorithm, Artificial Ant Colony, and Artificial Bee Colony. A summary of the references that support this research can be seen in Table 1 . 
Table 1. Literatur review.

\begin{tabular}{|c|c|c|c|c|}
\hline Paper & Purpose & Modification & Metod & Result \\
\hline $\begin{array}{l}\text { Idle Times } \\
\text { Analysis in } \\
\text { TALBP [6] }\end{array}$ & $\begin{array}{c}\text { Analising } \\
\text { with considers } \\
\text { idle time. }\end{array}$ & $\begin{array}{l}\text { Some measure of } \\
\text { solution are Balance } \\
\text { Delay (BD), Line } \\
\text { Efficiency (LE), } \\
\text { Line Time (LT), } \\
\text { dan Smoothness } \\
\text { Index (SI). }\end{array}$ & $\begin{array}{l}\text { Heuristic } \\
\text { method }\end{array}$ & $\begin{array}{l}\text { In TAL structure even } \\
\text { small changes of cycle } \\
\text { time cause changes of } \\
\text { the structure. } \\
\text { Additionally, some } \\
\text { delays times between } \\
\text { tasks be ignored at the } \\
\text { assembly line } \\
\text { structure. }\end{array}$ \\
\hline $\begin{array}{l}\text { TALB with } \\
\text { Assigment } \\
\text { Restriction [7] }\end{array}$ & $\begin{array}{l}\text { Minimize } \\
\text { cycle time } \\
\text { with the } \\
\text { assignment } \\
\text { made more } \\
\text { flexible dan } \\
\text { quick to } \\
\text { moved. }\end{array}$ & $\begin{array}{l}\text { Restrictions are } \\
\text { commonly } \\
\text { considered in } \\
\text { zoning restriction, } \\
\text { distance restriction, } \\
\text { synchronous task } \\
\text { restriction, resource } \\
\text { restriction, and } \\
\text { station restriction. }\end{array}$ & $\begin{array}{l}\text { Genetic } \\
\text { algorithm } \\
\text { and iterative } \\
\text { first-fit rule }\end{array}$ & $\begin{array}{l}\text { GA gave the result } \\
\text { better than IFFR. }\end{array}$ \\
\hline $\begin{array}{l}\text { TALBP with } \\
\text { Parallel } \\
\text { Performance } \\
\text { Capacity [8] }\end{array}$ & $\begin{array}{l}\text { Using a new } \\
\text { approach that } \\
\text { allows the } \\
\text { parallel } \\
\text { performance } \\
\text { of tasks. }\end{array}$ & $\begin{array}{l}\text { Examine the effect } \\
\text { of the parallel } \\
\text { performance of } \\
\text { paired tasks in } \\
\text { mated stations in a } \\
\text { TALBP problem. }\end{array}$ & $\begin{array}{l}\text { Linear } \\
\text { integer and } \\
\text { heuristic } \\
\text { algorithm }\end{array}$ & $\begin{array}{l}\text { The algorithm were } \\
\text { optimal for most of the } \\
\text { small problems } \\
\text { considered compared } \\
\text { with the solutions of } \\
\text { the mathematical } \\
\text { model produced. }\end{array}$ \\
\hline $\begin{array}{l}\text { An Effective } \\
\text { Discrete } \\
\text { Artificial Bee } \\
\text { Colony } \\
\text { Algorithm with } \\
\text { Idle Time } \\
\text { Reduction } \\
\text { Techniques for } \\
\text { TALBP of } \\
\text { Type-II [9] }\end{array}$ & $\begin{array}{l}\text { Reduction the } \\
\text { idle time. }\end{array}$ & $\begin{array}{l}\text { Specific design } \\
\text { tasks assignments to } \\
\text { eliminate idle time } \\
\text { depend on } \\
\text { sequence. }\end{array}$ & $\begin{array}{c}\text { Discrete } \\
\text { Artificial Bee } \\
\text { Colony } \\
\text { (DABC) }\end{array}$ & $\begin{array}{l}\text { A task assignment rule } \\
\text { is applied to a } \\
\text { decoding scheme that } \\
\text { can decrease } \\
\text { sequence-dependent } \\
\text { idle time. }\end{array}$ \\
\hline $\begin{array}{l}\text { Bee algorithms } \\
\text { for Parallel } \\
\text { TALBP with } \\
\text { Walking Times } \\
\text { [10] }\end{array}$ & $\begin{array}{l}\text { Introducing a } \\
\text { two-sided } \\
\text { assembly line } \\
\text { problem with } \\
\text { walking time. }\end{array}$ & $\begin{array}{l}\text { Walking distance is } \\
\text { included in the } \\
\text { problem of parallel } \\
\text { two-sided assembly } \\
\text { line balancing } \\
\text { problem. }\end{array}$ & $\begin{array}{c}\text { Bees } \\
\text { Algorithm } \\
\text { and Artificial } \\
\text { Bee Colony } \\
\text { Algorithm }\end{array}$ & $\begin{array}{l}\text { Walking times can not } \\
\text { be ignored for larger } \\
\text { assembly systems } \\
\text { because of the long } \\
\text { running distance } \\
\text { between production } \\
\text { lines. }\end{array}$ \\
\hline $\begin{array}{c}\text { TALB } \\
\text { Considering The } \\
\text { Relationships } \\
\text { between Task } \\
\text { [3] }\end{array}$ & $\begin{array}{l}\text { Completed the } \\
\text { two-sided } \\
\text { assembly line } \\
\text { balancing } \\
\text { problem with } \\
\text { consideration } \\
\text { of task } \\
\text { relation. }\end{array}$ & $\begin{array}{l}\text { The task } \\
\text { relationships } \\
\text { introduced are } \\
\text { distance factors and } \\
\text { tool factors. }\end{array}$ & $\begin{array}{l}\text { Simulated } \\
\text { Annealing }\end{array}$ & $\begin{array}{l}\text { Tasks that have more } \\
\text { connections provide } \\
\text { better opportunities to } \\
\text { be assigned to a public } \\
\text { station. }\end{array}$ \\
\hline
\end{tabular}




\begin{tabular}{|c|c|c|c|c|}
\hline Paper & Purpose & Modification & Metod & Result \\
\hline $\begin{array}{c}\text { TALB to Minimize } \\
\text { Number of } \\
\text { Workstation with } \\
\text { Consedering The } \\
\text { Relationship Between } \\
\text { Task (Dina } \\
\text { Rachmawaty - Next } \\
\text { Reserch) }\end{array}$ & $\begin{array}{c}\text { Two-sided } \\
\text { assembly line to } \\
\text { minimize } \\
\text { workstation with } \\
\text { consideration of } \\
\text { task relation factor } \\
\text { developed again. }\end{array}$ & $\begin{array}{l}\text { Relationship factor } \\
\text { assigned to } \\
\text { developed distance } \\
\text { factor, tool factor, } \\
\text { anthrophometry } \\
\text { factor, and skill } \\
\text { factor. }\end{array}$ & $\begin{array}{l}\text { Metaheuristic } \\
\text { Algorithm } \\
\text { (Genetic } \\
\text { Algorithm) }\end{array}$ & \\
\hline
\end{tabular}

\section{Development of Conceptual Model}

This conceptual model is developed based on model of Khorasanian et al. (2013). The initial model has function (1) and function (2).

$$
\begin{aligned}
& \mathrm{DF}_{\mathrm{ij}}=\left\{\begin{array}{c}
1,0 ; \text { if distance factor for } \mathrm{i} \text { and } \mathrm{j} \text { is "good" } \\
0,5 ; \text { if distance factor for } \mathrm{i} \text { and } \mathrm{j} \text { is "not good not bad" } \\
0,1 ; \text { if distance factor for } \mathrm{i} \text { and } \mathrm{j} \text { is "bad" }
\end{array}\right. \\
& T R_{i j}=a_{1} D F_{i j}+a_{2} T F_{i j} ; a_{1}+a_{2}=1
\end{aligned}
$$

Then added some factor so it becomes :

$D F_{i j}$ or $T F_{i j}$ or $M F_{i j}$ or $L F_{i j}$ or $S F_{i j}$

$$
\begin{gathered}
=\left\{\begin{array}{c}
1,0 ; \text { if distance factor for } \mathrm{i} \text { and } \mathrm{j} \text { is "good" } \\
0,5 ; \text { if distance factor for } \mathrm{i} \text { and } \mathrm{j} \text { is "not good not bad" } \\
0,1 ; \text { if distance factor for } \mathrm{i} \text { and } \mathrm{j} \text { is "bad" }
\end{array}\right. \\
T R_{i j}=a_{1} D F_{i j}+a_{2} T F_{i j}+a_{3} M F_{i j}+a_{4} L F_{i j}+a_{5} S F_{i j} ;
\end{gathered}
$$

Functions (3) and function (4) aims to provide an index of relationships according to the factors chosen and determined. Where DFij is a distance factor, TF $i j$ is a factor tool, $M F i j$ is a motion factor, $L F i j$ is a factor layout, $S F i j$ is a factor skill, and TRij is the reletionship value of all factors.

$$
\mathrm{ATC}=1-\frac{\sum_{\mathrm{k}=1}^{\mathrm{NS}}\left(\left(\sum_{\mathrm{i}=1}^{\mathrm{Nsk}} \sum_{\mathrm{j}=\mathrm{i}+1}^{\mathrm{Nsk}} \operatorname{TR}_{\pi \mathrm{sk}(\mathrm{i}), \pi \mathrm{sk}(\mathrm{j})}\right) /\left(\frac{\mathrm{Nsk}}{5}\right)\right)}{\mathrm{NS}}
$$

Function (5) describes the ATC to provide a solution of the relationship of a predetermined factor. The next function aims to minimize number of stations, minimize number of mated-station, and minimize ATC.

$$
\begin{aligned}
& S_{R}=[\text { RTtotal } / c t] \\
& S_{L}=[\text { LTtotal } / c t] \\
& S_{E}=\left[\max \left(\left(\text { ETotal }-\left(\left(S_{L}+S_{R}\right) X c t-(\text { LTotal }+ \text { RTotal })\right)\right), 0\right) / c t\right] \\
& L B_{N S}=S_{R}+S_{L}+S_{E}
\end{aligned}
$$




$$
L B_{N M}=\max \left(S_{L}, S_{R}\right)+\left[\max \left(\left(S_{E}-\left|S_{L}-S_{R}\right|\right), 0\right) / 2\right]
$$

Where RTtotal is the total processing time of the $\mathrm{R}$ type tasks, LTtotal is the total processing time of the L type tasks, and ETtotal is the total processing time of the E type tasks. ct represents cycle time and $[\mathrm{x}]$ denotes the smallest integer larger than or equal to $\mathrm{x}$. LBNS is denote the lower bounds of the number of station and LBNM is the number of mated-station.

Using these lower bounds, the number of stations and the number of mated-stations criteria were transformed into $\left(N S-\frac{L B_{N S}}{N S}\right)$ and $\left(N M-\frac{L B_{N M}}{N M}\right)$ respectively. So, the objective function is defined by the following equation:

$$
o b j=w_{1}\left(N S-\frac{L B_{N S}}{N S}\right)+w_{2}\left(N M-\frac{L B_{N M}}{N M}\right)+w_{3} A T C
$$

Where wi, $i=1,2,3$, are the user-defined weights of the factors. The number of matedstations may represent the line length. Also, the number of stations may denote the number of operators needed for the line. The effects of these two criteria on the efficiency of the line seem to be more than that of ATC. On the other hand, the number of stations is often considered more important than the number of mated-stations. Accordingly, w1 $>$ w $2>$ w 3 ; $\mathrm{w} 1+\mathrm{w} 2+\mathrm{w} 3=1$ should be satisfied.

Tables 2, 3, 4, 5, and 6 show the suggested values to be considered for each factor. The value has been tried to combine with all probability values so as to give a small ATC value. The smaller ATC values provide stronger factor relationships.

Table 2. Distance factor value.

\begin{tabular}{ccccc}
\hline Dfij & 1 & 2 & 3 & 4 \\
\hline 1 & - & 1,0 & 1,0 & 1,0 \\
2 & & - & 1,0 & 1,0 \\
3 & & & - & 1,0 \\
4 & & & & - \\
\hline
\end{tabular}

Table 4. Motion factor value.

\begin{tabular}{ccccc}
\hline Mfij & 1 & 2 & 3 & 4 \\
\hline 1 & - & 1,0 & 1,0 & 1,0 \\
2 & & - & 1,0 & 1,0 \\
3 & & & - & 1,0 \\
4 & & & & - \\
\hline
\end{tabular}

Table 6. Skill factor value.

\begin{tabular}{ccccc}
\hline Sfij & 1 & 2 & 3 & 4 \\
\hline 1 & - & 1,0 & 1,0 & 1,0 \\
2 & & - & 1,0 & 1,0 \\
3 & & & - & 1,0 \\
4 & & & & - \\
\hline
\end{tabular}

Table 3. Tool factor value.

\begin{tabular}{ccccc}
\hline Tfij & 1 & 2 & 3 & 4 \\
\hline 1 & - & 1,0 & 1,0 & 1,0 \\
2 & & - & 1,0 & 1,0 \\
3 & & & - & 1,0 \\
4 & & & & - \\
\hline
\end{tabular}

Table 5. Layout factor value.

\begin{tabular}{ccccc}
\hline Lfij & 1 & 2 & 3 & 4 \\
\hline 1 & - & 1,0 & 1,0 & 1,0 \\
2 & & - & 1,0 & 1,0 \\
3 & & & - & 1,0 \\
4 & & & & - \\
\hline
\end{tabular}

Table 7. Relationship value.

\begin{tabular}{ccccc}
\hline TRij & 1 & 2 & 3 & 4 \\
\hline 1 & - & 1,0 & 1,0 & 1,0 \\
2 & & - & 1,0 & 1,0 \\
3 & & & - & 1,0 \\
4 & & & & - \\
\hline
\end{tabular}




\section{Conclusion and Future Work}

The conclusion of the early stage in this research are valued factor and high proportion values can provide small relationship value so that additional factor is be effective in providing a solution for idle time reduction and minimize cycle time. Idle time and reduced cycle time can reduce the number of workstations so the work will be more effective.

Furthermore, the research will be applied to the observed object then compared the condition before the corrected with the suggestion of the value factor and after the improvement with the suggestion of given the value factor to know whether the modification of the model is right or not when applied to real condition.

\section{References}

1. Z. Li, I. Kucukkoc, J. M. Nilakantan, 84 (2017)

2. G. Tuncel,D. Aydin, Computers \& Industrial Engineering, 74 (2014)

3. J. Bartholdi, 31 (1993)

4. D. Kharosanian, S. Hejazi, G. Moslehi, Computer and Industrial Engineering Two, 66 (2013)

5. S. Wignjosoebroto, Ergonomi,Studi Gerak dan Waktu (PT. Guna Wijaya, 1995)

6. W. Grzechca, 7th IFAC Conference on Manufacturing Modelling, Management, and Control, 3-8 (2013)

7. H. Dwi, H. Wee, H. Rau, Mathematical and Computer Modelling, 57 (2013)

8. A. Sepahi, S. Gholamreza, N. Jalali, 40 (2016)

9. Z. Li, Q. Tang, L. Zhang, 97 (2016)

10. P. Tapkan, L. Ozbakir, A. Baykaso, 39 (2016) 